\title{
ПОЕТИЧНА АКТУАЛІЗАЦІЯ ВНУТРІШНЬОЇ ФОРМИ СЛОВА
}

У статті розглянуто приклади поетичної актуалізації внутрішньої форми слова (ВФС) на матеріалі української та російської поезії. Актуалізація ВФС відбувається завдяки контекстуальній сполучуваності, що підкреслює або відновлює мовні способи об'єктивації, серед яких походження в широкому розумінні, етимологічне, деривачійне, звукове, та інші форми смислового зближення в процесі функціювання. Віршова актуалізація ВФС $\epsilon$ емпіричним підтвердженням потебніанського тінгвопоетичного підходу до «свободи мови». У поезії ВФС породжує нові поетичні смисли, щзо виступають основою розвитку конкретного тіричного сюжету й підsрунтям подальшого розвитку мови.

Ключові слова: внутрішня форма слова, актуалізачія, поезія, контекстуальна сполучуваність, поетичні смисли.

Skorobohatova O. Poetic Actualization of the Inner Form of a Word. The founder of Kharkiv linguistic school O. Potebnia introduced the concept of language as an activity into the linguistic use. Recent studies prove that the concept of speech activity was used in the works of the founder of Geneva School, F. de Saussure. This concept has a prominent place in the linguistic theories of the above mentioned scholars. One of the forms of speech activity is the formation (in word-formation and etymological dimensions) and actualization (in speech and intertextual interactions) of the inner form of a word. The article considers some examples of poetic actualization of the inner form of a word and argues that poetic space is the creative sphere of its implementation. The relevance of the article lies in the significance of the theory of the inner form of a word for modern anthropocentric studies. The purpose of the article is to consider examples of poetic actualization of the inner form of a word and to establish the language basis for samples of poetic creative speech. Tasks: to describe examples of poetic actualization of the inner form of a word on the material of Ukrainian and Russian poetry; to find out the etymological or derivational factors of the poetic game, to single out actualization as a factor of speech and language dynamics. Conclusions. Actualization of the inner form of a word occurs due to contextual compatibility, which emphasizes or restores linguistic methods of objectification, including the origin in a broad sense, derivational, sound and other forms of semantic convergence in the functioning process. Poetic actualization of the inner form of a word is an empirical confirmation of Potebnia's linguopoetic approach to the "freedom of language". The unity of language and poetry, repeatedly pointed out by O. Potebnia, helps to understand the word, poetry, their interaction, connections and 
relationships. In poetry, the inner form of a world revives and creates new poetic meanings, which are the basis for the lyric plot development and the basis for further language development. The actualized inner form of a world becomes a factor of language dynamics and an object of study. Poetic reflection serves as a special method of studying the language and speech activity.

Key words: inner form of a word, actualization, poetry, contextual compatibility, poetic meanings.

\section{Вступ}

В. В. Бібіхін, розглядаючи різні тлумачення й вектори дослідження внутрішньої форми слова (ВФС) філологами й філософами кінця XIX - початку XX століття, влучно назвав розуміння О. О. Потебнею цього поняття поетичним. Ця характеристика теорії Потебні, на наш погляд, $є$ не лише метафорою: дослідник порівнює науковий доробок ученого з поетичною творчістю та вказує на декларований у роботі «Думка і мова» онтологічний зв'язок розвитку мови з поетичним баченням світу, розуміння поезії та поетичного мислення як рушійної сили мовної динаміки. Цю рушійну силу пізніше Р. О. Якобсон схарактеризує як поетичну функцію мови.

Дещо інший підхід, більш орієнтований на пошуки психологічного підгрунтя початку мови в царині логічного її розвитку, бачимо в теорії В. Гумбольдта, де «під знаком внутрішньої форми йдуть пошуки початку мови, того, що стоїьь за мовою, у підsрунті мови» (Бібіхін, 2008: 415) (виділено автором; тут і далі переклад наш - О. С.).

Потебніанське поетичне розуміння внутрішньої форми втрачене в розробках теорії ВФС на початку минулого століття, зокрема в роботах П. О. Флоренського та Г. Г. Шпета, хоча психологічний складник теорії Потебні ці вчені розглядали.

Ця стаття присвячена дослідженню «поетичного» складника теорії ВФС Потебні й вивченню шляхів актуалізації внутрішньої форми в поетичному тексті та дискурсі. Віршова актуалізація ВФС, на нашу думку, є емпіричним підтвердженням потебніанського лінгвопоетичного підходу до «свободи мови», задекларованої Гумбольдтом. Єдність поезії й мови, на яку неодноразово вказував О. О. Потебня, допомагає зрозуміти слово, поезію, їхню взаємодію, зв'язки та відношення. «Зрозуміти дію слова, і зокрема поезії, можемо, звичайно, тільки спостерігаючи властивості самого слова» (Потебня, 1976: 299), - декларує вчений. 
Актуальність статті полягає в значущості теорії ВФС для сучасних антропоцентричних розвідок. Мета статті - розглянути приклади поетичної актуалізації ВФС, установити мовне підгрунтя зразків віршового креативного мовлення. Завдання: 1) описати приклади поетичної актуалізації внутрішньої форми на матеріалі української та російської поезії; 2) з'ясувати етимологічні або дериваційні чинники поетичної гри, виокремити актуалізацію як чинник мовленнєвої і мовної динаміки.

\section{Методи дослідження}

Методологічною основою дослідження слугують діалектичні положення про єдність синхронії і діахронії, форми, структури й функції, форми та змісту, статичного та динамічного в мові й мовленні. Поєднано атомістичний і холістичний підходи до дослідження одиниць та їхнього функціювання в текстових фрагментах.

Основним теоретичним підгрунтям слугує вчення О. О. Потебні про ВФС. Застосовано комплексний системно-структурний і комунікативно-функційний підхід до вивчення одиниць, їхніх комбінацій і послідовностей. Використано описовий, дистрибутивний методи, методи контекстуального й інтерпретаційно-текстового аналізу.

\section{Виклад основного матеріалу}

Відомо, що ані Гумбольдт, ані Потебня не дали остаточної дефініції поняття ВФС. Читач їхніх наукових праць має можливість слідкувати за ходом думок науковців, спостерігаючи та поділяючи їх чи сперечаючись із ними: як реципієнт поезії стає співавтором художнього твору, так науковець долучається до створення і розуміння ідей разом з авторами теорії ВФС.

Одне з найвідоміших тлумачень поняття ВФС у О. О. Потебні таке: «Найближче етимологічне значення слова, той спосіб, яким виражений зміст» (Потебня, 1990: 22). Учений підкреслює, що внутрішня форма «спрямовує думку, <..> зважаючи на те, до яких сполучень воно ввійде з накопиченим у душі запасом, викличе те чи те уявлення в слові» (Там само). Учений не ототожнює ВФС з його етимологією, пов'язує іï з уявленням і функціюванням, процесом мислення та розуміє значно ширше: «Слово слугує лише точкою опори для думки. У міру застосування слова до нових й нових випадків ця 
невідповідність збільшується. Відносно широке й глибоке значення слова (наприклад, защита) прагне відірватися від відносно незначного / дрібного уявлення (взятого зі слова щъит), але в цьому прагненні породжує лише нове слово. Здобуті думкою нові точки прикріплення посилюють їі зростання» (Потебня, 1976: 302).

У праці «Думка і мова» вчений наголошує на властивості слова аперципувати думку: «Слово, узяте в цілому як сукупність внутрішньої форми й звука, $є$ насамперед засіб розуміти мовця, аперципувати зміст його думки» (Потебня 1976: 139). Якщо слово є сукупністю внутрішньої форми й звука, то до внутрішньої форми належить не лише наукова етимологія слова, але й усі значення полісемантичного слова, що функціюють і виокремлюються в мові (науковець уточнює, що «внутрішній зміст слова» і $€$ його «внутрішньою формою» (Там само: 138)). Народна або поетична етимологія, що спирається на співзвучність і паронімію, також є складником внутрішньої форми, оскільки вона грунтується на фонетичних зближеннях та в низці випадків може сприяти розумінню й тлумаченню сказаного.

На думку О. С. Снітко, що нам дуже близька, ВФС у потебніанському розумінні - це «результат мовної об'єктивації елементів суб'єктивного образу позначуваного» (Снитко, 1990: 4). Саме таке широке тлумачення ВФС дає можливості для сучасного розвитку теорії в річищі когнітивної, функційної та дискурсивної гуманітарних парадигм і їхніх лінгвістичних комбінацій.

Теоретики поетичного тексту й дискурсу кінця XX століття зазначають, що віршова мова в площині своєї формальної організації будується на несмислорозрізнювальних ознаках слова, а кожен мовний знак функціює в поетичному мовленні у своєму повному обсязі значень (Григорьев, 1990: 27). На жаль, у цих теоретичних працях теорія і навіть ім'я Потебні не згадується.

Неодноразово О. О. Потебня наголошував на тому, що актуалізація (зрозумілий та наявний експліцитний прояв) ВФС відбувається завдяки контекстуальній сполучуваності, що підкреслює, відновлює мовні способи об'єктивації, серед яких походження в широкому розумінні, етимологічне, дериваційне, звукове, або інші форми смислового зближення в процесі функціювання.

Відомо, що основний, етимологічний складник ВФ може бути прозорим (як у слів вікно, ведмідь, ворон та подібні), а може бути 
прихованим (як у слів луг, хитриц̆, вовк). Але навіть у слів, що належать до першого типу із цілком зрозумілим етимологічним значенням, у побутовому мовленні внутрішня форма зазвичай не проявляється, $\epsilon$ прихованою, бо іiі актуалізація не підтримана комунікативним завданням і векторами думки мовця та реципієнта. Наприклад, у слові колесо у фразі Треба колесо замінити внутрішня форма прихована, а в слові колобок вона більш наявна, зокрема в реченні Колобок покотився по дорозі.

Найкращий простір, у якому ВФС регулярно проявляється, підкреслюється, оживає, - це простір поетичний. Саме тут вона не лише відроджується, але й сама породжує нові поетичні смисли, що виступають основою розвитку конкретного ліричного сюжету й підгрунтям подальшого розвитку мови. Актуалізована ВФС в поетичному тексті й дискурсі стає одним із продуктивних чинників мовної динаміки та об'єктом художнього вивчення. Поетичні спостереження виконують роль особливого способу пізнання і мови, і мовної дійсності.

Розглянемо, наприклад, фрагмент поезії Михайла Ломоносова «Вечернее размышление о Божием величестве при случае великого северного сияния»:

Открылась бездна звезд полна;

Звездам числа нет, бездне дна.

У цьому фрагменті ми не лише можемо побачити класичний приклад так званої «поетичної філології» - художнього тлумачення внутрішньої форми слова бездна, але й зразок поетичної актуалізації мовного прототипу поняття 'відсутність' у російській мові: слова нет та прийменника / префікса без-. (про прототипи поняття «відсутність» див. Радчук, 2019). Поєднання в одному віршовому фрагменті двох прототипів свідчить про їхню когнітивну й мовну близькість. Кожен із прототипів несе власне навантаження, а вдвох вони створюють мінливий малюнок вірша, у якому значення 'відсутність' і 'відсутність відсутності' діалектично пов’язані (у сполученні числа нет репрезентоване стале енантіосемічне значення великої кількості.). Те, що значення величезної (надвеликої) кількості виражене прототипом поняття відсутність, указує на діалектичний зв'язок відсутності й наявності, а в конкретному ліричному наративі ототожнює їню Божу велич. Внутрішня форма повторюваного у фрагменті слова бездна виступає об'єктом авторського смислового й філологічного аналізу. 
За нашими спостереженнями, відірвана від наявності відсутність, що репрезентована згущенням часток не та нi, прийменників і префіксів без, в українському та російському поетичному дискурсі регулярно пов'язана з мотивами в’янення, смерті, небуття (див., наприклад, Скоробогатова, \& Минина, 2017). Поетичний дискурс актуалізує в мотивованих словах дериваційне й етимологічне значення морфем не-, нi-, без- за допомогою співпозиції з омонімічними частками й завдяки «згущенню» їх у тексті.

Прикладів поетичної актуалізації ВФС безліч, вони створюють неповторний зміст ліричного твору, оскільки не лише навколишній світ, але й сама мова постає об'єктом поетичних роздумів і рефлексій. Розглянемо, наприклад, поезію Павла Тичини «Арфами, арфами...», де художньо виділяється внутрішня форма прикметника перламутровий. Композицію цього ліричного тексту прикрашають повтори рядків Квітами-перлами / закосичена та Сміх буде, плач буде / перламутровий... Поєднання мотивувального іменника (перли) й мотивованого прикметника (перламутровий) у текстовій структурі не натяк, а занурення в природу мови й природу світу.

Не лише такий регулярний спосіб поетичної актуалізації форм і значень, як співположення однокореневих слів з прозорою етимологією здатен актуалізувати внутрішню форму, але й загальний зміст ліричного твору. Поетична думка в багатьох випадках підкреслює етимологічну або дериваційну ВФС. Наприклад, у Юрія Левітанського фіксуємо рядки:

\section{Бездна памяти, расширяющаяся Вселенная,} вся из края в край обжитая и заселенная...

(Ю. Левітанський «Память»)

О. М. Тихонов розглядає слово вселенная як непохідне (Тихонов, 1990: 423), а поет актуалізує його глибинне значення, що кальковане з грецької (ойкумена - «заселена земля»), у розгортанні поетичного роздуму. Співпозиція субстантивата Вселенная з дієприкметником заселенная підкреслює історичну кореневу тотожність. Слово, що за характеристикою Потебні для більшості носіїв мови є безобразним (першообразним), у поетичному просторі відроджує свої мовні зв'язки.

Розглядаючи питання ВФС, О. О. Потебня ретельно описує сполучення чесать косу, підкреслюючи етимологічну єдність сполучуваних 
слів. У художньому віршовому функціюванні поєднання синхронних і діахронних мотивувальних та мотивованих слів не є огріхом, прикрою випадковістю, тавтологією, а слугує прийомом художньої виразності, що відтворює особливості міфопоетичного мислення і світосприйняття. Фіксуємо в Лесі Українки спів заспівала, у Павла Тичини зелене зеленіє, вітра вітровіння, замулюється мулом, дзвінко дзвякали, у Володимира Свідзинського невольники волі, у Миколи Зерова n'є пиття, у Ліни Костенко дзвонять дзвони, в Олександра Пушкіна диво дивное, а в Йосипа Бродського дивныл дивы, у Юрія Левітанського пустая пустыня, загадыьвать загадки, в Анни Ахматової послал посла, в Олександра Галіча горькая горесть, метет метель. Кількість прикладів подібних поєднань у поетичному дискурсі величезна. Виникає питання: чому? Спробуємо знайти відповідь.

Міжчастиномовна й внутрішньокатегорійна співпозиція однокореневих слів виступає як загальнопоетичний прийом, що має прадавнє мовне й міфопоетичне підгрунтя. Праці із зіставної індоєвропейської лінгвістики й слов'янської лінгвопоетики свідчать, що такі комбінації в давніх мовах є дуже поширеними (див. Иванов, 1967: 99-110; Супрун, 1999 577-582; Топоров, 1990: 43-45). Вони мають значне когнітивне навантаження, оскільки відтворюють модель, у якій суб’єкт предикації або атрибуції виконує типову, зразкову, притаманну дію або має типову властивість.

У разі посилення кореневого значення (позитивна модель) сполучення породжує додатковий смисл 'природних', 'типових' дій і властивостей, як у сполученні чесать косу. Співпозиції чудо чудное або співати пісні в поезії нового та новітнього часу створюють додатковий поетичний ефект фольклорності, художньої традиційності, але, на відміну від моделей з постійним епітетом (добрий молодець або синє небо), традиційність не «розмиває» кореневе значення атрибута або предиката, а підкреслює його. Повтор кореня в цьому разі не є надлишковим, він виконує певну віршову стилістичну та смислову функцію.

Актуалізація ВФС в одному разі здійснюється прямо, а в іншому поступово, завдяки вишуканим прийомам і асоціаціям. Наприклад, у поезії Павла Тичини «Закучерявилися хмари» спостерігаємо співположення деривата з мотивувальним словом з безпосередньою зрозумілою актуалізацією: Я хочу бути - як забути?, а в поезії того самого 
періоду «Білі голуби злетіли...» в строфі Чорнобривщі, чорнобровки, / Станьмо всі під короговки! актуалізація первинного значення слова чорнобривці відбувається за допомогою співпозиції з відповідним фемінітивом, вокативній синтаксичній функції і лише у віршовому контексті набуває прихованого значення особи (у поєднанні з фразеологізмом стати під хоругви).

Актуалізація ВФС створює не лише мовні й індивідуально-авторські метафори, що докладно описав та обгрунтував О. О. Потебня, але й слугує підгрунтям формування інших тропів, наприклад, таким шляхом змодельовані оксюморони в сполученнях Ліни Костенко небуденні будні, забуті незабутні або невольники волі в поезії Володимира Свідзинського «В полум’ї був спервовіку...» (у згаданому творі Свідзинського фіксуємо також рядок 3 розсипаним пилом пилинки земної, де в сполученні пил пилинки відтворюються відносини частки й цілого).

У низці випадків підкреслюється динамічна синонімія, коли віршову співпозицію мають слова, що називають одне поняття в різні часи або в різних культурах. Наприклад, оксюморон у рядку Речь освободят от глагола Йосип Бродський створив, виділивши ВФС глагол, а значення слів парадиз, аркадия у фрагменті поезії «От окраины к центру» підкреслив співпозицією зі словом рай:

Вот я вновь посетил

эту местность любви, полуостров заводов,

парадиз мастерских и аркадию фабрик,

рай речных пароходов...

Апперцепція поетичної актуалізації ВФС має суб’єктивний характер. Потебня підкреслює, що, «оскільки почуття людини взагалі обумовлені сукупністю особистих властивостей людини, то й різниця ономато-поетичного слова має бути визнана a priori, але й вона $<\ldots>$ не заважає розумінню» (Потебня, 1976: 139).

Питання про те, свідомо чи підсвідомо поет використовує контекстуальне співположення (знає чи не знає він про етимологічну або дериваційну спорідненість слів), на наш погляд, є зайвим і недоречним. Віршова співпозиція стає реальністю ліричного твору незалежно від того, чи автор відчуває мовну близькість інтуїтивно, спираючись на своє лінгвальне чуття, чи має відповідні філологічні знання. У вислові всюду лежала толстая пыль, как жир / nустоты, 
так как в ней никто никогда не жил (Й. Бродський) створена катахреза. Один читач іiі відчує, зрозуміє, інший ні, але вона наявна в етимології слова жир, що прямо протилежна смислу наступного наративу в ней никто никогда не жил, який мовби пояснює смисл словосполучення жир пустоты. Що підштовхнуло поета, співзвучність слів жир і жил чи філологічні знання, по суті не має значення. Автор цих рядків у своїй Нобелівській промові назвав поета “знаряддям мови” (“орудием язика”), і ця теза знімає питання про свідомість або підсвідомість поетичного відбору. Процес актуалізації ВФС належить до когнітивних процесів перцепції та апперцепції, дослідження яких має сталу вітчизняну традицію.

Не лише поетичний текст, а й дискурс є простором відтворення ВФС. Актуалізована ВФС може виступати носієм і маркером інтертекстуальних зв'язків, наприклад, у поезії поета Максима Стативка «Надпись на камне» рядки Я дворянин с Клочковского двора / по улииам чужим иду упрямо відтворюють добре відому сучасному читачеві модель актуалізації ВФС Булата Окуджави Я дворянин с Арбатского двора, що має велике значення для розуміння змісту цього ліричного твору.

\section{Висновки}

Досліджений матеріал, на нашу думку, дає підстави стверджувати, що поезія є тією площиною, яку, услід за Потебнею, необхідно активно використовувати для вивчення лексичних і граматичних мовних явищ (звернемося хоча б до такого вислову вченого: «...про те, чи має рід смисл, можемо судити лише за тими випадками, де думці дана можливість на ньому зосередитися, тобто за творами поетичними» (Потебня, 1968: 452)), зокрема вивчення ВФС. Потебня першим у вітчизняному мовознавстві послідовно відстоював думку про те, що мова є особливою формою людської діяльності, і це твердження суголосне розумінню Ф. де Соссюром «актуальної процесуальної функції використання мови у мовній діяльності» щодо «визначення іiі функційної і прагматичної сутності» (Просяник, 2018: 105). Поетичний дискурс виступає площиною активної мовної діяльності, у якій індивідуальне мовлення відтворює мовні закономірності й системні зв'язки. У цьому аспекті вважаємо за доцільне продовжувати традиції Харківської лінгвістичної школи щодо поєднання суто мовознавчих 
і лінгвопоетичних векторів мовознавчих студій (Скоробогатова, 2019). Когнітивно-дискурсивний підхід, що його розвивають харківські мовознавці (див., наприклад, Чернцова, 2019) до дослідження мовних процесів та індивідуальних мовленнєвих фактів, послідовно відтворює принциповий теоретичний напрям цілісного інтегрального дослідження мовної системи, мовної діяльності й індивідуальноодиничних словесних феноменів.

\section{ЛIТЕРАТУРА}

1. Бибихин, В. В. (2008). Внутренняя форма слова. Санкт-Петербург: Наука. 2. Григорьев, В. П. (Ред.). (1990). Очерки истории языка русской поэзии ХХ века. Поэтический язык и идиостиль: Общие вопросы. Звуковая организащия текста. Москва: Наука. 3. Иванов, В. В. (1967). Использование для этимологических исследований сочетаний однокоренных слов в поэзии на древних индоевропейских языках. Этимология 1967. Материаль международного симпозиума «Проблемы славянских этимологических исследований в связи с общей проблематикой современной этимологии» (с. 40-56). Москва: Наука. 4. Потебня, А. А. (1968). Из записок по русской грамматике. Об изменении значения и заменах существительного. (Т. 3). Москва: Просвещение. 5. Потебня, А. А. (1976). Эстетика и поэтика. Москва: Искусство. 6. Потебня, А. А. (1990). Теоретическая поэтика. Москва: Высш. шк. 7. Просяник, О. П. (2018). Фердинанд де Соссюр: демібологізація концепиії. Харків: Харк. іст.-філол. т-во. 8. Радчук, О. В. (2019). Лингвокогнитивная репрезентаиия понятия «отсутствие» в русском языке. Харьков: Юрайт. 9. Скоробогатова, О. (2019). Поетичне мовлення як джерело граматичних студій: Харківська філологічна школа та лінгвістика XXXXI ст. В Петро Олексійович Лаврівський: наукова і науково-критична спадщина (до 190-річчя від дня народження) (с. 33-46). Киев: Вид. дім Дмитра Бураго. 10. Скоробогатова, Е. А., \& Минина, Н. С. (2017). Грамматические значения и поэтические смыслы: стиховая актуализация служебных частей речи. Харьков: ФЛП Бровин А. В. 11. Снитко, Е. С. (1990). Внутренняя форма номинативных единиц. Львов: Свит. 12. Супрун, А. Е. (1999). Древяно-полабское *pesnaj pot 'песни петь'. В Поэтика. История литературы. Лингвистика: Сборник к 70-летию Вячеслава Всеволодовича Иванова (с. 577-582). Москва: ОГИ. 13. Тихонов, А. Н. (1990). Словообразовательный словарь русского языка. Словообразовательные гнезда. (Т. 1. А-П). Москва: Русский язык. 14. Топоров, В. М. (2010). Мировое дерево. Универсальные знаковые комплексы. (Т. 1). Москва: Рукописные памятники Древней Руси. 15. Чернцова, Е. В. (2019). Дискурсивное варьирование когнитивной семантики слова: опыт интегрального исследования (на материале глагольных предикатов казаться, показаться, девербатива кажимость, парентезы кажется). Харьков: ХНУ имени В. Н. Каразина.

\section{REFERENCES}

1. Bibixin, V. V. (2008). Vnutrennyaya forma slova [The inner form of the word]. Sankt Petersburg: Nauka [in Russian]. 2. Grigor'ev, V. P. (Ed.). (1990). Ocherki istorii yazyka russkoj poe'zii XX veka. Poe'ticheskij yazyk i idiostil': Obshhie voprosy. Zvukovaya 
organizaciya teksta [Essays on the history of the language of Russian poetry of the $20^{\text {th }}$ century. Poetic language and idiostyle: General questions. Sound organization of the text]. Moskva: Nauka [in Russian]. 3. Ivanov, V. V. (1967). Ispol'zovanie dlya e’timologicheskix issledovanij sochetanij odnokorennyx slov v poézii na drevnix indoevropejskix yazykax [Use for etymological research of combinations of same-root Words in poetry in ancient Indo-European languages]. In E'timologiya 1967. Materialy mezhdunarodnogo simpoziuma «Problemy slavyanskix e'timologicheskix issledovanij $v$ svyazi s obshhej problematikoj sovremennoj e'timologii - Etymology 1967. Proceedings of the International Symposium "Problems of Slavic Etymological Research in Connection with the General Problems of Modern Etymology" (pp. 40-56). Moskva: Nauka [in Russian]. 4. Potebnya, A. A. (1968). Iz zapisok po russkoj grammatike. Ob izmenenii znacheniya i zamenax sushhestvitel'nogo [From notes on the Russian grammar. About changing meaning and substitutions of a noun]. (Vol. 3). Moskva: Prosveshhenie [in Russian]. 5. Potebnya, A. A. (1976). Estetika ipoe'tika [Aesthetics and poetics]. Moskva: Iskusstvo [in Russian]. 6. Potebnya, A. A. (1990). Teoreticheskaya poe'tika [Theoretical poetics]. Moskva: Vyssh. shk. [in Russian]. 7. Prosianyk, O. P. (2018). Ferdynand de Sossiur: demifolohizatsiia kontseptsii [Ferdinand de Saussure: demythology of the concept]. Kharkiv: Khark. ist.-filol. t-vo [in Ukrainian]. 8. Radchuk, O. V. (2019). Lingvokognitivnay a reprezentaciya ponyatiya «otsutstvie» $v$ russkom yazyke [Linguo-cognitive representation of the concept of "absence" in the Russian language]. Xar'kov: Yurajt [in Russian]. 9. Skorobohatova, O. (2019). Poetychne movlennia yak dzherelo hramatychnykh studii: Kharkivska filolohichna shkola ta linhvistyka XX-XXI st. [Poetic speech as a source of grammar studies: Kharkiv Philological School and Linguistics of the XX-XXI centuries.]. In Petro Oleksiiovych Lavrivskyi: naukova i naukovo-krytychna spadshchyna (do 190-richchia vid dnia narodzhennia) - Petro Oleksiiovych Lavrivskyi: scientific and scientific-critical heritage (to the 190th anniversary of his birth) (pp. 33-46). Kyiv: Vyd. dim Dmytra Buraho [in Ukrainian]. 10. Skorobogatova, E. A., \& Minina, N. S. (2017). Grammaticheskie znacheniya i poe'ticheskie smysly: stixovaya aktualizaciya sluzhebnyx chastej rechi [Grammatical meanings and poetic meanings: verse actualization of the functional parts of speech]. Xar'kov: FLP Brovin A. V. [in Russian]. 11. Snitko, E. S. (1990). Vnutrennyaya forma nominativnyx edinic [The inner form of nominative units]. L'vov: Svit [in Russian]. 12. Suprun, A. E. (1999). Drevyano-polabskoe *pesnaj pot 'pesni pet" [Polabian *pesnaj pot 'to sing song']. In Poe'tika. Istoriya literatury. Lingvistika: Sbornik $k$ 70-letiyu Vyacheslava Vsevolodovicha Ivanova - Poetics. Literary history. Linguistics: Collected works for the 70th anniversary of Vyacheslav Vsevolodovich Ivanov (pp. 577-582). Moskva: OGI [in Russian]. 13. Tixonov, A. N. (1990). Slovoobrazovatel'nyj slovar' russkogo yazyka. Slovoobrazovatel'nye gnezda [Word-formation dictionary of the Russian language. Word-building family]. (Vol. 1. A-P). Moskva: Russkij yazyk [in Russian]. 14. Toporov, V. M. (2010). Mirovoe derevo. Universalnye znakovye kompleksy [The world tree. Universal iconic complexes]. (Vol. 1). Moskva: Rukopisnye pamyatniki Drevnej Rusi [in Russian]. 15. Cherncova, E. V. (2019). Diskursivnoe var'irovanie kognitivnoj semantiki slova: opyt integral'nogo issledovaniya (na materiale glagol'nyx predikatov kazat'sya, pokazat'sya, deverbativa kazhimost', parentezy kazhetsya) [Discourse variation of word cognitive semantics: the experience of integral research (based on verbal predicates казаться, показаться, deverbative кажимость, parenthesis кажemcr)]. Xar'kov: KhNU imeni V. N. Karazina [in Russian]. 
Скоробогатова Олена Олександрівна - доктор філологічних наук, доцент, професор кафедри зарубіжної літератури та слов'янських мов, Харківський національний педагогічний університет імені Г. С. Сковороди; вул. Валентинівська, 2, м. Харків, 61168, Україна.

Tel. 050-902-72-91

E-mail: skorobogatova.elena@gmail.com

https://orcid.org/0000-0003-0214-1889

Skorobohatova Olena Oleksandrivna - Doctor of Philological Sciences, Docent, Professor at the Department of Foreign Literature and Slavic Languages, H. S. Skovoroda Kharkiv National Pedagogical University; 2 Valentynivska Str., Kharkiv, 61168, Ukraine.

Надійшла до редакції 14 березня 2021 року

\section{CITATION}

ДСТУ 8302:2015: Скоробогатова О. О. Поетична актуалізація внутрішньої форми слова. Лінгвістичні дослідження: зб. наук. пр. Харк. нац. пед. ун-ту імені Г. С. Сковороди. Харків, 2021. Вип. 54. Ч. I. C. 185-196. DOI: https://doi.org/10.34142/23127546. 2021.54.1.16

APA: Скоробогатова, О. О. (2021). Поетична актуалізація внутрішньої форми слова. Лінгвістичні дослідження, 54 (I), 185-196. DOI: https://doi.org/10.34142/23127546. 2021.54.1.16 